\title{
Metabolic energy changes during exercise in equines
}

This article was published in the following Dove Press journal:

Veterinary Medicine: Research and Reports

25 November 2010

Number of times this article has been viewed

\author{
Linda M Shecterle \\ John A St.Cyr \\ Jacqmar, Inc., Minneapolis, MN, USA
}

Correspondence: LM Shecterle, Jacqmar, Inc., 10965 53rd Avenue North, Minneapolis, MN 55442, USA

$\mathrm{Tel}+\mathrm{I}$ 763-473-3007

Cell + I 612-998-9783

Fax + I 763-383-5I55

Email Ims94@aol.com

\begin{abstract}
High-intensity exercise can lower skeletal muscle energy levels in equines. Publications have substantiated this decline in muscular adenosine triphosphate (ATP) levels following intense exercise sessions. Adequate energy levels are crucial for the maintenance of cellular integrity and function. D-ribose, a natural occurring carbohydrate, enhances the regeneration in muscular ATP levels following stressful conditions and has the potential to play a substantial role in energy recovery following high-intensity exercise. The following commentary addresses the altered metabolic energy state during exercise in equines.
\end{abstract}

Keywords: equines, energy, ATP, D-ribose

\section{Commentary}

Skeletal muscle function is dependent on adequate cellular levels of adenosine triphosphate (ATP). The production of ATP is continuous; however, during states of metabolic stress, such as ischemia, hypoxia, and high-intensity exercise, these levels are reduced, and studies have shown that the recovery can be prolonged. ${ }^{1}$ Utilization of ATP without concomitant regeneration produces a cellular energy deficiency. Furthermore, continued catabolism of adenine nucleotides eventually produces nucleosides, which can potentially diffuse across a cell's membrane, further limiting ATP regeneration.

During high-intensity anaerobic exercise, the cell's ability to produce adequate levels of ATP is stressed, where demand can exceed supply. Human studies have reported a decline in skeletal ATP levels following high-intensity exercise, where as much as 3 days are required for complete return. ${ }^{1}$ Similar results have been reported in equines subjected to high-intensity training/racing conditions. Hodgson reported a decline in equine skeletal muscle ATP levels during periods of high-intensity exercise. ${ }^{2}$ Harris et al reported a minimal decrease in skeletal muscle ATP levels in horses during treadmill exercise at a speed of $10 \mathrm{~m} / \mathrm{sec}$, but a significant decline up to $47 \%$ was observed when equines were paced at a $12 \mathrm{~m} / \mathrm{sec} .{ }^{3}$ Because of a presumed decline in muscular energy levels following high-intensity exercise, race horses are routinely rested following a race to maximize a return in muscular energy levels. In conjunction with a deficiency in energy levels with high-intensity exercise, oxygen free radical production increases during times of muscular stress.

D-ribose, a natural occurring pentose carbohydrate, regenerates ATP levels following stress. ${ }^{1}$ D-ribose has shown to reduce the drain on energy molecules during ischemia (Figure 1). In humans, the supplementation of D-ribose around high-intensity exercise has demonstrated a lower decline and a shortened recovery interval in regenerating submit your manuscript $\mid$ www.dovepress.com

Dovepress

DOI: 10.2147 IVMRR.S15289
Veterinary Medicine: Research and Reports 2010:1 I-2

(C) 2010 Shecterle and St.Cyr, publisher and licensee Dove Medical Press Ltd. This is an Open Access article which permits unrestricted noncommercial use, provided the original work is properly cited. 
Riboso helps reduce the energy toll of ischemia

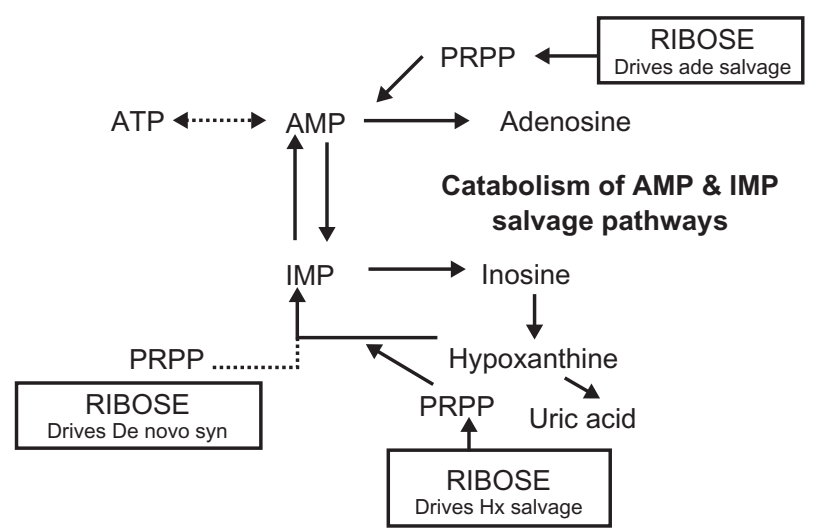

Figure I Ribose regulates activity of de novo and salvage pathways of nucleotide metabolism.

Abbreviations: ATP, adenosine triphosphate; AMP, adenosine monophosphate; PRPP, 5-phosphoribosyl-I-pyrophosphate; IMP, inosine monophosphate; $\mathrm{Hx}$, hypoxanthine.

muscular ATP levels. D-ribose has also shown a benefit in limiting the increased production of oxygen free radicals following stress. ${ }^{4}$

Equine trainers and owners have noted benefits with either D-ribose alone (20 to $60 \mathrm{~g} / \mathrm{dose}$ ), or in combination with other ingredients, such as glucosamine, chondroitin sulfate, dimethylglycol, vitamins, and minerals. ${ }^{5}$ Subjectively, many have observed an enhanced energy state the day of and following the race, with less down time following a race and less post race joint swelling, not requiring significant therapies. ${ }^{5}$ D-ribose has also shown energy benefits to the heart during stressful conditions without untoward consequences. Schneider et al reported the enhancing recovery of ATP levels and function with D-ribose following global myocardial ischemic stress. ${ }^{6}$ This natural carbohydrate should be given consideration for its enhancing energy benefits following stressful conditions, including high-intensity exercise.

\section{Disclosure}

The authors declare no conflicts of interest in this work.

\section{References}

1. Dodd SL, Johnson CA, Fernholz K, St.Cyr JA. The role of ribose in human skeletal metabolism. Med Hypotheses. 2004;62(5):819-824.

2. Hodgson DR. Energy considerations during exercise. Vet Clin North Am Equine Pract. 1985;1(3):47-60.

3. Harris RC, Marlin DJ, Snow DH, Harkness RA. Muscle ATP loss and lactate accumulation at different work intensities in the exercising thoroughbred horse. Eur J Appl Physiol. 1991;62(4):235-244.

4. Seifert JG, Subudhi AW, Fu MX, et al. The role of ribose on oxidative stress during hypoxic exercise: a pilot study. J Med Food. 2009;12(3):690-693.

5. van Tassel RK, Butler TL, St.Cyr J. Compositions to reduce exerciseinduced swelling of joints. Patent application \#20040147458, 2004.

6. Schneider JR, St.Cyr JA, Mahoney JR, Bianco RW, Ring WS, Foker JE. Recovery of ATP and return of function after global ischemia. Circ (Part II). 1985;72(4):III-298.
Veterinary Medicine: Research and Reports

\section{Publish your work in this journal}

Veterinary Medicine: Research and Reports is an international, peer-reviewed, open access journal publishing original research, case reports, editorials, reviews and commentaries on all areas of veterinary medicine. The manuscript management system is completely online and includes a very quick and fair peer-review system. Visit http://www.

\section{Dovepress}

dovepress.com/testimonials.php to read real quotes from published authors. 